\title{
Discussion on E-commerce Practice Teaching Reform under New Business Background
}

\author{
Yun-qiu JIAO* \\ Economy and Management College \\ Weifang University \\ Weifang, China
}

\begin{abstract}
This paper takes e-commerce talents training in the new business background as research object, deeply discusses the problems such as unreasonable curriculum system, the imperfect laboratory construction, and lack of deep industry-university cooperation. In view of the above practical problems, this paper adopts method combining practical research and theoretical analysis, and proposes the reform strategies: constructing a new business e-commerce practice innovative talent training system, optimizing practical teaching curriculum system, constructing a comprehensive practice platform, and building the practical teaching base.
\end{abstract}

Keywords-capacity development; e-commerce talent; practical teaching; industry-university integration

\section{INTRODUCTION}

With the rapid development of e-commerce, the demand for purely technical talents in e-commerce has begun to decrease, and the demand for innovative and complex new business talents who have mastered both network information technology and business management are growing. In the talent market, the phenomenon of "recruitment difficulties" and the "difficult employment" of college graduates coexist. The main reason for the "dilemma" is that the e-commerce talents cultivated by colleges and universities generally have relatively weak hands-on ability, insufficient innovation ability and a single knowledge structure. It is not enough to learn ecommerce based on theoretical knowledge, and it is necessary to put the knowledge learned into practice through practical operation $^{[1]}$. It can be said that practical teaching is an important way to improve students' practical ability and innovative ability, and to improve students' professional ability and comprehensive quality. Therefore, as for local applied undergraduate colleges, they should pay attention to the integration of production and education, strengthen the cooperation between schools and enterprises, and actively promote the practice teaching reform oriented to the ability training, so as to cultivate innovative and composite ecommerce talents that meet the characteristics of the new era.

This research was financially supported by Ministry of Education Industry-University Cooperation Collaborative Education Project (201802323013), Ministry of Education Industry-University Cooperation Collaborative Education Project (201801069109), Ministry of Education Industry-University Cooperation Collaborative Education Project (201801114030)

\section{Problems IN E-COMMERCE Practice}

\section{A. Homogenization of Training Objectives and Inaccuracy of} Professional Positioning

Some local undergraduate colleges lack systematic research and overall design when formulating the training objectives of business majors, and the combination of regional economic and social development needs is not deep enough. Therefore, the training objectives are generally homogenized and do not reflect the characteristics, and professional positioning is not accurate enough. Neglecting the cultivation of students' innovative and entrepreneurial ability, is far from the actual demand for innovative and complex new business e-commerce talents, which affects the quality of talent training.

\section{B. Unreasonable Set of Curriculum System and Single Structure of Knowledge}

The new business is a new fusion of knowledge and skills, which tends to be industry-oriented. It emphasizes the characteristics of the industry and develops students through professional developing skills. Students can determine the direction of industry according to their own interests, therefore, the new business model pays more attention to the cultivation of students' practical ability. At present, in many colleges and universities, some curriculum system, practice courses and theoretical courses are often set independently, with less practice time, and are focused on basic practice, lack of comprehensive practical training. In addition, neglecting crossprofessional linkage, lack of cross-professional courses and innovative entrepreneurship curriculum, are also problems in curriculum system ${ }^{[2]}$. As a result, the students' knowledge structure is unreasonable, and their practical and innovative abilities are obviously insufficient.

\section{Imperfect Laboratory Construction and Existing Problems}

At present, many local colleges and universities mainly adopt the operation of simulation software inside the school laboratory, to enable students to understand various links and operational processes of e-commerce. However, because the simulation software itself has the disadvantages of high price, imperfect function and easy outdated, the laboratory often suffers from problems such as insufficient capital investment, limited space, and slow software update, which mainly embodied in the following aspects: 
a. With the continuous development of e-commerce, it is often facing the problem that hardware cannot keep up with software, and it is difficult to meet the practical teaching needs.

b. Most colleges and universities purchase experimental software for e-commerce simulation, network marketing and online payment, but the convergence of these software is not strong, even is independent to each other.

c. The development of e-commerce is changing rapidly, thus the purchased simulation software will soon lag behind the development of internet. The software cannot be updated in time, and the latest technology of e-commerce cannot be fully reflected.

$\mathrm{d}$. The laboratory has a single function and cannot meet the teaching needs of cross-border e-commerce experiments. Cross-border e-commerce experiments is required to closely integrate the production practices of e-commerce, international trade, international logistics, finance and other related industries, and to build a full-process practical teaching platform, which should have multidisciplinary crossover, combination, integration and teaching skills ${ }^{3]}$.

e. Existing simulation software lacks real environment and data. Manufacturers only provide software, do not provide key data such as product information and enterprise information. A large amount of information requires random input by students, and these data are quite different from real business data, and cannot show the real business environment. This kind of simulation software may make students unable to handle the real business problems, even if they are quite skilled in software operations.

\section{Lack of Deep School-Enterprise Cooperation, and Non- Effectiveness of Practice}

Although many colleges and universities have their own off-campus practice bases, on the one hand, some companies are small, their e-commerce-related jobs are less able to receive large numbers of students; on the other hand, some companies do not form a joint platform, which has not substantive cooperation project for cultivating talents. There are often many considerations such as trade secrets, operational safety, and production rhythm, so these companies are unwilling to accept students to do practice, and they are not active or cooperative.

\section{E. Lack of High-Level Practical Guidance Teachers}

From the perspective of allocation of teachers, the first thing is that, colleges and universities are required to have doctoral degrees in the introduction of talents. Most of the professional teachers go directly to colleges and universities after graduation, who have no actual e-commerce work experience. Due to the lack of practical experience, they often stay at the level of theoretical knowledge in the teaching process, and are not qualified for practical teaching. Secondly, due to the lack of corresponding supporting measures, the enthusiasm of teachers to go to the company for training is not high. The third thing is to hire teachers from enterprises, but when the outside school tutor was employed, due to the qualification, time, funding and management issues, large-scale implementation difficulties were arising. Therefore, a high level of practical instructors with practical experience is very scarce.

\section{COUNTERMEASURES AND RECOMMENDATIONS}

\section{A. Improving Talent Training Program Oriented to Ability Training}

Based on the combination of regional industrial structure upgrading and new business talent training, talent training should further clarify the training objectives of the compound and applied talents, and train students to become new business talents with high innovation consciousness, professional accomplishment and solid professional skills. Therefore, when formulating talent training programs, we should highlight the ability training of students, implement innovative credits, and equip with project instructors, so as to develop students' vision through the class and practical semester, enhance students' practical ability, and promote e-commerce practice oriented to capacity development ${ }^{[4]}$.

In the construction of practical conditions, we will carry out all-round cooperation with enterprises, to build an e-commerce innovative talent training system (as shown in Fig. 1).

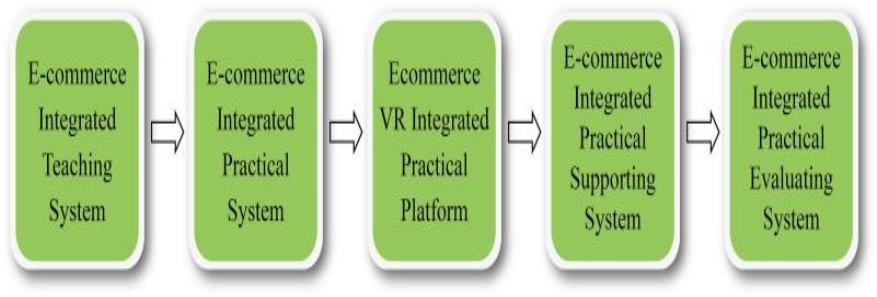

Fig. 1 New business e-commerce practical innovative talent training system

The training system mainly starts from the e-commerce comprehensive teaching system, e-commerce comprehensive practice system, the e-commerce VR comprehensive practice platform, e-commerce comprehensive practice support system, and the e-commerce comprehensive practice quality evaluation system. Combining the characteristics of school-enterprise cooperation under the new situation, we will build a "threedimensional" full-process e-commerce comprehensive practice education framework for students, enterprises and universities; explore the comprehensive e-commerce practice school-school collaboration, school-site collaboration, and school-enterprise collaboration. The synergistic education mechanism formulates and improves practical management measures for relevant comprehensive practical education; implements the "five-inone" teaching system for comprehensive e-commerce training courses, scientifically sets the teaching system for e-commerce curriculum and e-commerce comprehensive training practice links, including credit management; increases the whole process and comprehensive assessment, and creates a training evaluation feedback system.

\section{B. Optimizing E-Commerce Practice Teaching Curriculum System}

In order to implement the new business e-commerce talent training model, it is necessary to establish and improve the curriculum system, especially to optimize the practical 
curriculum system and increase the proportion of experimental teaching. It is necessary to pay attention to the deep integration of production and education, reconstruct the curriculum system, optimize the knowledge structure, and update the practical teaching content and innovative teaching methods. It is necessary to gradually construct a practical teaching curriculum system, which integrates professional cognition, corporate cognition, curriculum training, comprehensive training, post scenario real simulation, graduation internship, and graduation design (graduate thesis). Combined with e-commerce VR training process, the actual work tasks of each specific post, teachers can design and implement the practical teaching contents, which can improve students' comprehensive practical ability and professional quality training.

\section{Strengthening Laboratories Construction and Improving Comprehensive Practice Platform}

New business talents must not only possess professional knowledge, but also have the ability to communicate, unite and cooperate, love and dedication, and learn to innovate. It is difficult to develop students' ability through classroom teaching. Based on characteristics of new business talents, simulation laboratory, inter-disciplinary comprehensive training room, SYB laboratory, simulation bank, business software laboratory, VBSE laboratory, entrepreneurship training room, and ecommerce VR comprehensive laboratory, should all be constructed to ensure that students can conduct coursework through the virtual simulation platform for business practice.

In the hardware configuration of the laboratory, it is necessary to increase the funding and site investment of the ecommerce laboratory. There should be unified planning, not only to meet the daily needs of e-commerce teaching, but also to keep pace with the times. In terms of software provision, not only it must be equipped with the basic simulation teaching software for learning, but also be integrated with the modules of e-commerce, international trade, logistics management, marketing and finance. To form the e-commerce VR comprehensive practice platform, it should be integrated with a high degree of of professional knowledge, fine integration of business processes, and practical operation of skills (see Fig. 2) By expanding and perfecting the new business e-commerce VR comprehensive practice platform, the students' knowledge is effectively expanded, so that students can truly understand the business flow, capital flow, and logistics operation mode of ecommerce, and can simulate the cross-border e-commerce practice process. Which will help to improve students' practical ability and analytical ability, improve students' ability of innovation and entrepreneurship, and achieve the goal of learning and improving in practice.

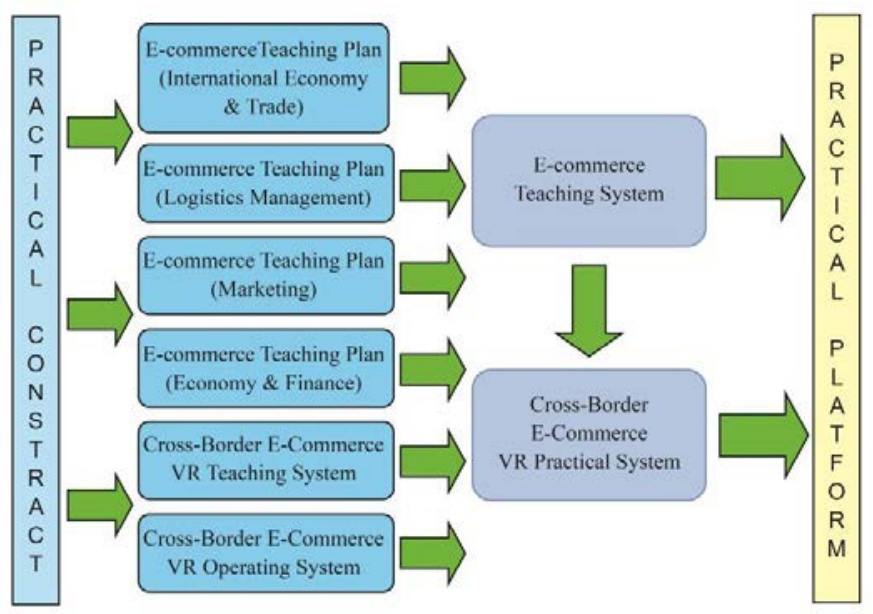

Fig. 2 New business e-commerce VR integrated practice platform

\section{Strengthening School-Enterprise Deep Cooperation and Building Practical Base}

Colleges and universities should actively explore a new model of industry-university integration and collaborative education, strengthen in-depth cooperation with enterprises, and jointly build a comprehensive collaborative education platform, that integrates education, training and research and development in line with industry standards. Both schools and enterprises give full play to their respective advantages, and jointly undertake the guidance of students' internship training, subject competition and graduation thesis; the preparation of teaching materials; the evaluation and supervision of practical teaching; the training of enterprise employees; the research and development of product technology; the transformation of scientific research results, etc. On the one hand, the school can timely understand the new technology, new industry standards and new professional needs, and adjust the practical teaching system in real-time; it can use the real business data and environment of the enterprise to better cultivate students' practical ability, innovation and entrepreneurial ability, and improve teachers' practical teaching ability and scientific research ability. On the other hand, enterprises can use the human resources and scientific research strength of the school, to organize scientific and technological research, train staff skills, and improve marketing capabilities. They can solve business problems through competition projects, and can select suitable talents ${ }^{[5]}$.

\section{E. Building Disciplinary Competition Training Platform and Perfecting Practical Teaching System}

Relying on professional laboratories, building the competition training platform, organizing students to participate in various discipline competitions, cultivating college students' teamwork spirit, innovative thinking and solving practical problems; promoting teaching through competition, and promoting competition training to further improve the teaching reform of practical courses. Integrate the subject competition into the practical curriculum, integrate the curriculum into enterprise project and social service, and truly achieve the integration of course competition and integration of production and learning. Actively organize students to 
participate in the "Challenge Cup" National Undergraduate Entrepreneurship Competition, the National College Student ECommerce" Innovation, Creativity and Entrepreneurship" Application Contest, the National College Student Foreign Trade Competence Competition (POCIB), and the "National College Student ERP Sand Table Simulation Contest", can improve students' practical application ability and innovation and entrepreneurial ability.

\section{F. Building an Excellent Teaching Team}

Colleges and universities should take effective measures to increase the intensity of external training, and establish a "double-skilled" faculty with strong theoretical and practical skills and reasonable personnel structure. We can cultivate a solid foundation of theoretical knowledge and rich practice by encouraging professional teachers to pursue interdisciplinary studies, domestic and international visits, job training, guiding discipline competitions, studying for degrees, obtaining vocational competency certificates, and participating in seminars and exchanges. Experience can be engaged in the subject theory teaching, but also familiar with the professional teachers of business operations. At the same time, engineers and technicians with many years of work experience and higher education, can be hired as part-time teachers to participate in ecommerce by offering professional courses, holding special lectures, guiding students' course design, subject competition, production internship, graduation design, etc., thus can improve the effectiveness of practical teaching ${ }^{[6]}$.

\section{G. Conducting Entrepreneurship Education and Guidance, Cultivating Students' Practical Ability}

Combining the characteristics of e-commerce, we use existing internet resources to educate students about entrepreneurship practice. The most effective way to master ecommerce skills is real operation. When students already have basic knowledge and basic theories of business operations, encourage them to go out of the lab and make full use of the real, free and abundant resources of the internet, to let students know the operation process of real business activities, and guide students to do online shopping, online store operating, We-chat marketing, etc., allowing students to learn, operate, and operate, so as to better improve students' e-commerce combat capabilities. When students practice online store activities, they should be honest in the form of a team, not too profitable.

\section{CONCLUSION}

E-commerce has entered a new era of online and offline deep integration, e-commerce model, format, product, service diversification and international development. The society has a higher demand for the quantity and quality of e-commerce talents. This requires schools to pay more attention to the practical teaching of new business e-commerce, strengthen the cooperation between schools and enterprises, and actively promote the practice teaching reform-oriented to capacity training, so as to cultivate innovative and complex e-commerce talents that meet the characteristics of the new era.

\section{ACKNOWLEDGMENT}

This research was financially supported by Ministry of Education Industry-University Cooperation Collaborative Education Project (201802323013), Ministry of Education Industry-University Cooperation Collaborative Education Project (201801069109), Ministry of Education IndustryUniversity Cooperation Collaborative Education Project (201801114030).

\section{REFERENCES}

[1] Chen Jianke, "Discussion on the construction mode of e-commerce laboratory,” Chinese \& Foreign Entrepreneurs, vol. 6, 2019, pp. 236-238 (In Chinese).

[2] Li Baoqin, "Research on the practice teaching reform of e-commerce courses for non-e-commerce majors in colleges and universities," Journal of Hotan Teachers College, vol. 4, 2015, pp. 38-42 (In Chinese).

[3] Tian Juanjuan, "Discussion on the cultivation of financial professionals in the context of new business," Co-Operative Economy \& Science, vol. 4, 2019, pp. 112-113 (In Chinese).

[4] Qiao Xianyu, Xiong Li, "A practical combat-oriented e-commerce practice teaching reform discussion," Experimental Technology and Management, vol. 11, 2015, pp. 174-176 (In Chinese).

[5] Ren Jiajia, "Research on the construction of practical teaching system for e-commerce in applied undergraduate colleges,” E-Business Journal, vol. 5, 2019, pp. 69-70 (In Chinese).

[6] Wu Qingyan, "Research on the innovation of e-commerce practice teaching,” E-Business Journal, vol. 11, 2015, pp. 78-79 (In Chinese). 